\title{
Enhancing Board Monitoring Tasks: The Effect of Minority-Elected Directors
}

\author{
Sara De Masi ${ }^{1} \&$ Andrea Zorzi ${ }^{1}$ \\ ${ }^{1}$ Department of Economics and Management, University of Florence, Italy \\ Correspondence: Sara De Masi, Department of Economics and Management, University of Florence, Italy. \\ E-mail: sara.demasi@unifi.it
}

Received: May 7, 2020

Accepted: May 28, 2020

Online Published: June 8, 2020

doi:10.5539/ijbm.v15n7p85

URL: https://doi.org/10.5539/ijbm.v15n7p85

\begin{abstract}
In companies with a controlling shareholder the agency relationship between controlling shareholders and minority shareholders poses significant issue. Managers may pursue, rather than the interests of the company as a whole, the interest of the controlling shareholder. When there is a controlling shareholder, independent directors may not prove sufficient to monitor the management behaviour, given that they are ultimately appointed by the same controlling shareholder whose possible opportunistic behaviour they are meant to constrain. Therefore, minority shareholders may be given appointment rights to the board: directors elected by minority shareholders may work as a corporate governance mechanism that fosters the board's willingness and ability to monitor managers' behaviour, on the assumption that managers are appointed by the controlling shareholder. This paper examines empirically whether having a minority-elected director on corporate boards increases the ability of the board to monitor management behaviour. Using a sample of the largest listed Italian companies in years 2008-2017, we find that minority-elected directors have a positive and statistically significant effect on board monitoring tasks. We also document that this effect is higher when they are elected by institutional investors. Our results have important implications for policy makers and, more generally, corporate governance best practice in all contexts in which companies have a concentrated ownership structure.
\end{abstract}

Keywords: Corporate governance, minority shareholders, board of directors, list voting, slate voting, dissident directors, minority-elected directors

\section{Introduction}

Independent directors are a staple of basically all governance laws and best practices (Armour, Enriques, Hansmann \& Kraakman, 2017), although they were originally introduced in jurisdictions where ownership is dispersed, and the main agency costs arise from the relationship between managers and shareholders. In that context, their function is to serve as a monitoring device to ensure that managers would act in the interest of shareholders (Armour et al., 2017). However, they were subsequently 'imported' to countries with concentrated ownership structures, where their function somewhat shifted; depending on jurisdictions, they may be meant to protect the interests of shareholders, of the company as a whole, or of stakeholders (Ferrarini \& Filippelli, 2014).

In companies with concentrated ownership the most relevant opportunistic behaviour refers to the relationship between the controlling shareholder and minority shareholders. When there is a controlling shareholder, minority shareholders are at risk of expropriation (Claessens, 2002) typically by means of tunnelling, self-dealing and related party transactions at unfair terms (Enriques, 2018). Controlling shareholders, while generally beneficial in terms of firm performance (Goshen \& Squire, 2017), may use their influence to extract private benefits of control (Shleifer \& Vishny, 1997; Dick \& Zingales, 2004) and induce managers to make decisions to their only advantage (Denis \& McConell, 2003). Therefore, in companies with controlling shareholders, corporate governance devices - including independent directors - should be directed at preventing this kind of opportunistic behaviour.

In companies with controlling shareholders, however, independent directors may be not enough to prevent that controlling shareholders would act together with managers in order to put in place actions at the expense of minority shareholders. Notwithstanding the fact that the definition of directors' independence usually includes independence from the controlling shareholder, given that they are usually elected by the controlling shareholder, their monitoring ability may be weakened. 
Therefore, recent literature has stressed the need to increase the effectiveness of board monitoring over management behavior and identify mechanisms to reduce agency costs in the context of companies having controlling shareholder (Bebchuk \& Hamdani, 2017). Some jurisdictions have gone so far as to provide that at least some independent directors are elected by minority shareholders. This is the case of Italy, where this mechanism dates back significantly, as will be illustrated below.

Minority-elected directors are meant to curb controlling shareholders' opportunistic behaviour, and, more in general, may ensure a more diverse and balanced structure of the board which can translate into more board effectiveness in performing its monitoring tasks.

The monitoring ability of boards with minority-appointed directors may be stronger when minority-appointed directors are elected by institutional investors (Enriques, Hansmann, Kraakman \& Parglender, 2017). While it is unclear whether institutional investors have a positive effect on firm value (Cremers \& Sepe, 2018), it is undoubted that the general trend is towards institutional investment engagement (Rock, 2018; Hill 2018), and their role in corporate governance is the assumption on which recent EU law rests (Directive (EU) 2017/828 of 17 May 2017 - Shareholder Rights Directive 2), although not specifically with regard shareholders' interests, but rather broader objectives (see, e.g., Recitals 14, according to which ' $[\mathrm{g}]$ reater involvement of shareholders in corporate governance is one of the levers that can help improve the financial and non-financial performance of companies, including as regards environmental, social and governance factors' and 15, '[i]nstitutional investors and asset managers are often important shareholders of listed companies in the Union and can therefore play an important role in the corporate governance of those companies, but also more generally with regard to their strategy and long-term performance').

Anectodal evidence demonstrates how institutional investors have become more active in Italy in their monitoring role since the end of the Noughties, sometimes leveraging on their ability to elect a director (Belcredi \& Enriques, 2014).

This paper aims at testing empirically whether having minority-elected directors on the board increases board monitoring tasks. It also investigates whether there is a difference in board monitoring when the minority-elected directors are elected by institutional investors. Italy gives a perfect context to test these research questions. The problem of monitoring the private benefits of the largest shareholders is particularly relevant in Italy, where corporate governance is characterized by family ownership and shareholders' agreements (Zattoni, 2007; Rigolini \& Huse, 2018) and, as mentioned, Italian law provides the possibility to appoint minority shareholders through slate voting.

Our results find that corporate boards with minority-elected directors are more engaged in board monitoring. We also document that the monitoring effect is higher when minority-elected directors are elected by institutional investors.

This research aims to enrich the existing literature in two ways. Firstly, we shed light on an additional corporate governance mechanism that may be employed to increase the ability of the board to monitor management behaviour. Secondly, we clarify the relevance of the monitoring role of minority-elected directors that are appointed by institutional investors.

\section{Election of Independent Directors in Controlled Companies: Cumulative Voting and Recent Alternatives}

In principle, independent directors may be particularly effective in monitoring and protecting the shareholders' interests. However, in companies with a controlling shareholder, directors, including independent directors, are usually all elected by the controlling shareholder. This poses an obvious issue of structural independence which could question their ability and willingness in monitoring and protecting non-controlling shareholders's interests. Although it is acknowledged that independence is, in the first place, a matter or character and spirit, owing election and re-election to the controlling shareholder is a serious threat to proper independence. (For widely held companies, to the contrary, the issue of election and re-election is solved by demanding that nominations are not in the domain of the CEO or other executives: hence the use of nomination committees made entirely of independent directors).

Various systems have been devised to afford some control over (at least some) independent directors to non-controlling shareholders: the idea is that the presence of directors elected by minority shareholders or, at a minimum, elected with some form of control by minority shareholders would increase board monitoring and would better protect the interests of minority shareholders.

The most classic methods of enabling election by shareholders other than the controller is cumulative, 
proportional and 'list' or 'slate' voting and, as a matter of fact, rules enabling the appointment of one or more directors by minority shareholders are a common feature in company laws across jurisdictions. Both cumulative (or proportional) and slate voting have the effect of making it possible for shareholders who are not in control of the company (very often, setting a minimum threshold) to appoint directors on the board. With cumulative voting, the number of directors that can be elected by minorities is usually roughly proportional to the number of votes available to the minority. Cumulative voting was a quite common feature for US public companies until the Sixties but had some significant issues especially with regard to coordination costs and because of the leverage it afforded to raiders in hostile takeovers (Gordon, 1994). In all cases, it was not mandatory and, given the freedom of choice in corporate law in the US, cumulative voting basically disappeared.

Recently, however, the argument of enhancing structural independence of independent directors in controlled companies has resurfaced, also in the light of the now more common ownership structure in which institutional investors' holdings are so significant (Gilson \& Gordon, 2019). Bebchuk and Hamdani (2017) proposed a system by which public investors have a veto over the election over a certain number of directors (which are still elected by the controlling shareholder) and have the exclusive right to re-elect such director (Bebchuk \& Hamdani, 2017). The system was put into practice in Israel; a similar system, limited to the vetoing phase, also exists in the UK (Strampelli, 2018). Some countries - not many - mandate proportional or cumulative voting (Passador, 2008), but thresholds to ensure the election of a director tend to be high (e.g. Brazil sets the threshold to $10 \%$ of preferred stock or $15 \%$ of common stock - Enriques et al., 2017). Thus, slate voting as devised in Italy sets itself apart from other systems and appears an important corporate governance device in a context of concentrated ownership.

It should be noted that Italy and, more generally, continental Europe (Faccio \& Lang, 2002) are indeed not the only jurisdictions in which publicly traded companies have a controlling shareholder. This true also in Asia (Claessens, Djankov \& Lang, 2000) and even in the U.S. (Holderness, 2009). Therefore, the results of this article can be extended way beyond Italy.

\section{The Italian 15-Year-Long Experience of 'Slate Voting' and Some Hypotheses: Legal Environment and Empirical Literature}

\subsection{Italian Rules on the Election of Directors by a Minority of Shareholders}

Italy gives an interesting context to test the effect of minority-appointed directors. The issue of expropriation of minorities, absent a serious threat of judicial enforcement of duty of loyalty as long as the company is solvent, is a staple of Italian corporate governance (Enriques \& Volpin, 2007; Gelter, 2012; Gerner-Beuerle \& Schuster, 2014) and the law has struggled to find self-enforcing systems to avoid expropriation. In companies with a controlling shareholder the board monitoring tasks translate into controlling the largest shareholders and managers who may take actions to increase their wealth at the expense of minority shareholders.

In this context, in 2005 (effective since 2007) Italy introduced a mandatory provision by which minority shareholders can elect at least one director.

One of the objections to minority-elected directors is that such appointment power could give too much edge to minority shareholders who might want to engage in opportunistic behaviour to obtain a benefit for themselves only, at the expense of other minority shareholders, rather than pursuing the interests of all minority shareholders. In the Italian context, given the common ownership structure, it was believed that such risk was actually outweighed by the expected advantages of having minority-elected directors monitor the board in order to limit minority shareholder expropriation.

As a matter of fact, the aforementioned risk of opportunistic uses by aggressive activists and non-institutional investor blockholders apparently did not materialise, also due to the active role taken on by the Italian Asset Managers' Association, which, as will be better explained below, has a leading role in nominations and elections of minority-elected directors, especially in larger companies.

Traditionally, Italian companies opting to allow minority shareholders to be represented on the board of directors use either the technique of 'slate voting' or that of 'proportional' voting (which also requires separate slates, but does not pre-determine the number of seats assigned to the minority), but it was never a mandatory provision, until twenty-five years ago.

Mandatory slate voting for the appointment of directors and statutory auditors was first introduced in Italy at the time of privatisation of State-owned companies (1994) in a very specific context and only for privatised companies.

In 1998, the Consolidated Act on Finance (Legislative Decree No. 58 of 24 February 1998) introduced 
mandatory minority shareholder representation in the board of statutory auditors. The context was very different: the provision was for the first time meant as a measure to empower minorities and to limit expropriation by controlling shareholders (Ventoruzzo, 2007).

Finally, with the 'Act for the Protection of Investors' of 2005 (No. 262 of 28 December 2005), enacted after the financial scandals of the early 2000 s, slate voting became mandatory also for the election of directors. The provision became fully effective in June 2007; given that general shareholder meetings are usually in April or May, only since 2008 it was certainly in force for all companies.

The clear intent of the legislator was to curtail expropriation by controlling shareholders, by creating a category of super-independent directors or, as now termed, 'enhanced independence directors' (Bebchuk \& Hamdani, 2017; Strampelli, 2018), who actually do seem to act accordingly to their enhanced independence (Marchetti, Siciliano, \& Ventoruzzo, 2017; Passador, 2018; Marchetti, Siciliano, \& Ventoruzzo, 2020).

One of the interesting features of the mandatory provision is that minority shareholder appointment must be made possible by bylaws but is by no means mandatory in itself.

More in detail, Italian law mandates that all listed companies' boards comprise at least two independent directors (if, as is normally the case, the board has more than seven members) (art. 147-ter(4), Consolidated Act on Finance, Legislative Decree 24 February 1998, No. 58, as amended); for companies of the FTSE-MIB segment (top tier of the market), such as those analysed in this article, the Italian Code of Corporate Governance requires that at least one third of the board is made up of independent directors (Comitato per la Corporate Governance, 2018). In practice, about one half of board members are independent (in 2018, the mean was 4.9 vis-à-vis an average board size of 9.8 (Consob, 2019)).

In addition to independent directors, whose presence is mandatory, all companies must have in place a rule by which at least one director can be elected by minority shareholders, unrelated to controlling shareholders (Art. 147-ter(1), (1-bis), and (3), Consolidated Act on Finance). Thus, at least one seat of the board is reserved for a minority-elected director. Technically, this is done by 'list' o 'slate' voting. Each shareholder can put forward only one list, or slate, of nominees; some companies - especially so-called 'privatised' ones, whose clauses date back to the first wave of minority-elected directors, of 1994 - provide for more than one seat on the board. The bylaws must provide that at least one seat goes to the first candidate of the slate that garnered the second greatest number of votes. Companies can set a minimum threshold to present slates of candidates, but these thresholds cannot go beyond a certain percentage, which is quite low and vary based on the company's market capitalization. The general threshold is $2.5 \%$, apart for some exeptions in which it is set at $4.5 \%$, but is set at $1 \%$ for companies whose market capitalization is between euro 1 bln and 15 bln and at $0.5 \%$ above that market capitalization (Art. 144-quarter, Consob Regulation on Issuers, No. 11971 of 14 May 1999, as amended). Hence, the presence of a minority-elected director requires that a minority shareholder does, in fact, present a slate, but the required percentage is not a serious hindrance.

\subsection{The Italian Experience, in Practice: The Effects on Board Monitoring Ability}

In practice, minority-elected directors are on many, but indeed not on all listed companies' boards (as of 2017, 98 companies out of 231 listed on the Italian stock exchange had minority-elected directors; in 2018, it was 110 out of 218) (Consob, 2018 and Consob, 2019).

Nominating a prospective minority-elected director has a cost and the usual collective-action issues may make it not worth for a shareholder to undergo the process. The only known existing empirical study, referred to years 2008-2010, finds a significant effect of size of the company on the presence of minority-elected directors and finds a somewhat counterintuitive negative correlation between the size of the controlling shareholders' stake and the presence of minority-elected directors (Belcredi, Bozzi, \& Di Noia, 2013). The same study finds support for what it calls a 'regulatory hypothesis', that is that the presence of minority-elected directors is influenced by specific regulatory features and differences in details of regulation.

In the past ten years, since the last study by Belcredi et al. (2013), Assogestioni, the Italian Asset Managers' Association has become a dominant force in submitting minority slates. Assogestioni, by means of a formalised procedure, submits minority candidates which are previously vetted for competence and independence. The number of companies in which Assogestioni submits candidates has almost doubled in this time span (Assogestioni, 2018). The stepping in of Assogestioni basically has created a natural experiment that allows to test the 'enhanced independence' hypothesis.

As mentioned above, according to our view, minority-elected directors should have a positive effect on board monitoring ability. 
Bianchi, Ciavarella, Enriques, Novembre \& Signoretti (2014) find that companies where there is at least one minority-elected director (elected by institutional investors) have stricter regulations regarding related-party transactions. This shows that there is an enhanced attention of boards which include minority-elected directors towards transaction that can be used to expropriate minority shareholders. Passador (2018) shows that minority-elected directors are effective in improving the governance of listed companies in favour of shareholders as a class. Specifically, she shows that minority-elected directors increase the propensity to pay dividends, reducing the free cash flow available for managers to be invested in projects that may increase the largest shareholders' wealth at the expense of minority shareholders. Marchetti et al. (2017) show that minority-elected directors tend to express their dissent more, relative to other directors, thus signaling to challenge the main viewpoint and be particularly engaged in the scrutiny activates and the monitoring function. Marchetti et al. (2020) document that minority-elected directors have a positive impact on the amount and the quality of disclosure of information. This means that minority-elected directors, increasing the corporate transparency, may be an effective corporate governance mechanism which protects minority shareholders' interests.

Based on the above discussion we posit the following hypothesis:

Hypothesis 1. Boards with minority-elected directors are more engaged in monitoring tasks than boards with no minority-elected directors.

In Italy, the role of institutional investors has grown over time: for example, institutional investors' attendance to general meetings has increased dramatically in the past 10 years (Consob, 2019). Previous research shows mixed results related to the effect of institutional investors on monitoring. Smith and Olper and Sokobin find that institutional investors bring a positive effect on monitoring (Smith, 1996; Olper \& Sokobin, 1996). Other studies document that institutional investors may be less effective in monitoring since they are more likely to use the 'exit option' (i.e. sale of the shares) rather than the 'voice option' when they dissent from the management (Goergen, 2012; Hirschman, 1971). In the case of Italy, Bianchi and Enriques (2001) argued in the past that, in principle, institutional investors suffer conflicts of interests that may prevent them to use their voice in the general meetings. However, the scene has changed in the last decade. Belcredi and Enriques (2014) bring significant anectodal evidence to the fact that institutional investors have taken up a more active role and explain this, to a more favorable regulatory framework, alongside reasons connected with the structure of the market.

\subsection{The Role of Institutional Investors}

Firm-specific activism (which does indeed exist and is not uncommon: Erede, 2013; Balp, 2019) is not the only form of engagement of institutional investors in Italy. Probably the most important form of engagement is the one carried out by the Italian Asset Manager Association, Assogestioni, mentioned previously. Since 2005, Assogestioni assists and coordinates its members in selecting candidates and presenting slates for the elections on the board of directors and the board of auditors. In 2007, the first year in which slate voting was available in (almost) all companies, it presented slates for directors in 7 companies; in 2019, in 30 companies (Assogestioni, 2007 and Assogestioni, 2019) (it should be noted that directors are usually elected for a three-year term in Italy, hence the number should be trebled to capture the actual magnitude of Assogestioni's engagement).

Whilst a director elected by a minority shareholder (a blockholder) other than an institutional investor could, in theory, be an effective monitor, it is possible that, rather than confronting the controlling shareholder and the managers expressed by the controlling shareholder, it may collude with the controlling shareholder to take part in the extraction of private benefits at the expense of other minority shareholders (not represented by the board) or, at a minimum, will pursue its own agenda, which could conflict with the interests of other minority shareholders. To the contrary, when the director is elected by institutional investors, even if the director pursues the interest of its elector, it will be pursuing, normally, the interest of a shareholder who represents the interests of the market and, thus, of all shareholders. There may be exceptions - the institutional investor may also have an agenda that conflicts with the interests of other shareholders - but that does not seem the norm (Belcredi \& Enriques, 2014). This tendency to pursue the interests of all shareholders as a class can be expected even more if the director stems from a coalition of institutional investors, as is the case of Assogestioni. We can therefore expect a more attentive monitoring by a director elected by institutional investors in the framework of their association.

Based on the above discussion we posit the following hypothesis:

Hypothesis 2. Boards with minority-appointed directors elected by Assogestioni are more engaged in monitoring tasks than boards with minority-elected directors elected by other minority shareholders. 


\section{Methodology, Sample and Variables}

Our sample includes the largest listed companies in Italy (FTSE-MIB companies) during the years 2008-2017. We collected detailed information regarding ownership and governance. Governance data are downloaded by Datastream, ASSET4 ESG database. This database provides detailed information about corporate governance and financial statements. Specifically, based on companies' annual reports on corporate governance, financial statements or any other publicly available documents related to companies' corporate governance, the database collects information about certain corporate governance policies for guiding the behaviour of board members.

Information about minority-elected directors was hand collected from company reports (annual accounts; corporate governance reports, when available; general meeting minutes; slates of candidates presented by shareholders) and other publicly available information (filings with the Italian securities commission).

To test our hypotheses, we estimate the following regression models of firm $\mathrm{j}$ :

$$
\begin{array}{r}
\text { MONITORING }_{j,}=\alpha_{1}+\beta_{1} \text { MINORITY DIRECTORS }_{\mathrm{j}}+\beta_{2} \text { CONTROL_VARIABLES }_{\mathrm{j}}+\varepsilon_{\mathrm{j}} \\
\text { MONITORING }_{j,}=\alpha_{1}+\beta_{1} \text { INSTITUTIONAL INVESTORS }_{\mathrm{j}}+\beta_{2} \text { CONTROL_VARIABLES }_{\mathrm{j}}+\varepsilon_{\mathrm{j}}
\end{array}
$$

Where $\alpha$ is the constant, $\beta$ is the coefficient, $\varepsilon$ is the residual term.

Our dependent variable is MONITORING, which assesses the board commitment towards the monitoring of managers' behaviours. Based on detailed, textual information about each firm regarding corporate board policies for guiding the behaviour of its members, our dependent variable indicates (1) whether the board has a policy that ensures monitoring over management, (2) whether the policy is implemented and (3) whether the board exercises monitoring tasks through the establishment of board committees.

All of this information is transformed by Datastream into a score that is calculated by equally weighting and z-scoring all underlying data points and comparing them against those of all companies in the ASSET4 ESG database. Z-Score is a relative measure comparing one company with a given benchmark. It reflects a company's monitoring performance relative to the average monitoring performance of all other companies that are rated by Datastream ASSET4. It expresses the value in units of standard deviation of that value from the mean value of all companies (Wooldrige, 2008; Glantz, Slinker and Neilands, 2016). The z-scores are normalized, which entails that Datastream ASSET4 scales the z-scores in order to make them fit into the range of zero to hundred. The resulting measures, among other things, allows to create more distinction between values that otherwise might be very close together (Kreyszig, 1979). A higher score indicates a better ability of the board to perform monitoring tasks.

Our explanatory variable MINORITY DIRECTORS is a dummy variable assuming the value 1 if the board has at least one director elected by minority shareholders. The coefficient of the dummy variables measures the contribution of minority directors for board monitoring tasks.

INSTITUTIONAL INVESTORS is our second explanatory variable. It is a dummy assuming the value 1 if the minority directors are elected by Assogestioni, then Italian Asset Managers' Association.

We include control variables related to board characteristics that affect the ability of the board members to complete their tasks (Dalton, Daily, Ellstrand \& Johnson, 1998; Huse \& Nielsen, 2010; Minichilli, Zattoni \& Zona, 2009; Zona \& Zattoni, 2007). BOARD SIZE, calculated as the number of members on the board, is assumed to significantly influence the ability of the board to monitor managers and CEOs (Core, Holthausen \& Larcker 1999; Bebchuck \& Fried, 2004). INDEPENDENT DIRECTORS is measured as the percentage of independent directors reported by the company. The higher the number of independent directors is, the stronger the ability of the board to monitor managers. CEO DUALITY is a dummy variable that is equal to 1 if the CEO is also the chairman and zero otherwise. CEO-chairman separation may be beneficial for monitoring tasks since in the case of CEO duality, there would be constraints on board members' capacity to ask critical questions and obtain correct answers (Daily \& Dalton, 1997). All variables are defined in Table 1. 
Table 1. Variables description

\begin{tabular}{ll}
\hline Variable & Description \\
\hline Monitoring tasks & It is a score that measures the board capacity to pursue its monitoring function. This capacity is assessed \\
when the board has a policy that ensures monitoring over the management, whether the policy is \\
implemented and whether the board exercise monitoring task functions through the establishment of board \\
committees. The score is calculated by equally weighting and z-scoring all underlying data points and \\
comparing them against all companies in Datastream. The resulting percentage is therefore a relative \\
measure of performance, z-scored and normalized to better distinguish values and position the score \\
between 0 and $100 \%$. A $\mathrm{Z}$ Score, or 'standard score' expresses the value in units of standard deviation of \\
that value from the mean value of all companies. \\
It is a dummy variable that assumes the value 1 if a board has a director elected by minority shareholder; 0 \\
otherwise. \\
Institutional invest a dummy equal to 1 if the minority director is elected by Assogestioni; 0 otherwise. \\
Board size & The total number of board members at the end of the fiscal year. \\
CEO duality & It is a dummy equal to 1 if the CEO is also Chairman; 0 otherwise. \\
Independent directors & Percentage of independent board members as reported by the company.
\end{tabular}

\section{Empirical Analysis}

Before starting the regression analysis, we first examine the descriptive statistics of the variables used in this study (Table 2). The average board size is 12 members. In $37 \%$ of the cases, the minority director(s) is elected by Assogestioni. The average percentage of independent directors is $54 \%$. In $20 \%$ of the sample, CEO is also the Chairman.

Table 2. Descriptive statistics

\begin{tabular}{llllll}
\hline Variable & Obs & Mean & Std. Dev. & Min & Max \\
\hline Monitoring tasks & 352 & 56.79 & 26.84 & 3.68 & 95.05 \\
Minority directors & 265 & 0.64 & 0.48 & 0 & 1 \\
Institutional invest & 408 & 0.37 & 0.48 & 0 & 1 \\
Board size & 300 & 12.18 & 4.59 & 4 & 25 \\
CEO duality & 352 & 0.20 & 3.18 & 0 & 1 \\
Independent directors \% & 327 & 54.33 & 21.76 & 0 & 100 \\
\hline
\end{tabular}

Table 3 shows the contribution of minority directors to monitoring tasks. Hypothesis 1 posits that boards with directors appointed by minority shareholders are more enganged in board monitoring than boards with no minority-elected directors. The result confirms Hypothesis 1 . The impact of minority directors on monitoring tasks (model 1) is positive and statistically significant (coeff. $=8.21$, p-value $<0.05$ ). This finding confirms that minority directors are a corporate governance mechanism that enhances board monitoring.

Looking at directors elected by institutional investors which are coordinated by Assogestioni, the effect of board monitoring is higher (coeff. $=12.76$; $p$-value $<0.01$ ). Hypothesis 2 is accepted.

Our results provide evidence on the role of minority directors in board monitoring. When they are included in the board, the board monitoring becomes more stringent. This means that directors appointed by minority shareholders helps to reduce potential agency costs between controlling shareholders and minority shareholders. Specifically, boards with minority appointed directors devolve more resources in overseeing top management, thus decreasing the possibility that top management make decisions led by opportunistic behavior. Moreover, our results shed light on the monitoring role of institutional investors in Italy: When the director is elected by institutional investors and is nominated by their association (the Italian Asset Manager Association, Assogestioni), board monitoring becomes even more stringent. This result suggests that directors appointed by institutional investors pursue the interests of shareholders as a class, given that their monitoring, in a market with a prevalence of controlled companies, is directed to curtailing expropriation of minority shareholders.

Regarding the control variables, independent directors have a positive effect on board monitoring. This is in line with the literature that views independent directors as a first mechanism to protect shareholders' interests. The variable 'board size' is positive and statically significant, indicating that large boards are more engaged in monitoring. This result appears in contrast to a stream of research that indicates that large boards have more 
coordination problems and less communication that could lead inineffective monitoring (Eisenberg Sundgren \& Wells, 1998; Yermack, 1996). Future research will be needed to understand whether there are idiosincratic reasons that may explain this.

Table 3. Regression analysis

\begin{tabular}{lll}
\hline & Monitoring tasks & Monitoring tasks \\
\cline { 2 - 3 } & $(1)$ & $(2)$ \\
\hline Minority directors & $8.21^{* *}$ & \\
& $(2.03)$ & $12.76^{* * *}$ \\
Institutional invest. & & $(3.93)$ \\
& & $0.27^{* * *}$ \\
Independent directors \% & $0.22^{* *}$ & $(3.58)$ \\
& $(2.14)$ & -2.13 \\
CEO duality & -2.98 & $(-0.53)$ \\
& $(-0.70)$ & $1.67^{* * *}$ \\
Board size & $2.49^{* * *}$ & $(4.50)$ \\
& $(5.31)$ & YES \\
Years & YES & YES \\
Industries & YES & 272 \\
N. Obs & 241 & 0.21 \\
Adj R & 0.15 & \\
\hline
\end{tabular}

Note. Ordinary linear regressions. T-statistics are in parentheses. The levels of significance are $* \mathrm{p}<0.1 ; * * \mathrm{p}<0.05 ; * * * \mathrm{p}<0.01$. Definition of the variables are in Table 1 .

\section{Conclusion}

Our research question addresses the effect of directors elected by minority shareholders on board monitoring tasks. We provide evidence that companies with directors elected by minority shareholders are more engaged in board monitoring. This engagement is stronger if the director is elected by institutional investors.

To the extent that the monitoring task is a priority, as occurs when ownership structure favours possible opportunistic behaviour (as is the case with controlled companies), it should be considered whether having minority-elected directors is a corporate governance device that should be adopted more intensively. Specifically, when the market for corporate control is not a viable option to reduce agency costs, and ownership structure is dominated by controlling shareholder, independent directors alone may be not enough to avoid the risk of expropriation of minorities. In this corporate governance context minority-elected directors could be more reliable monitors than other corporate governance mechanisms.

Moreover, minority elected directors nominated by institutional investors may be also seen as a tool through which the shareholder activism would be strengthened. This could contribute to change the role of institutional investors in Italy moving the country away from its reputation as "a world of controlled capitalism" (Financial Times, 2017).

Additionally, our results have important implications for shareholders and policy makers all over the world. Although concentrated ownership is a common feature in many European (Faccio \& Lang, 2002) and Asian countries (Claessens, Djankov, \& Lang, 2000) also in U.S. the relationship between controlling shareholders and minority shareholders may be a concern. Using a representative sample of U.S. public firms, Holderness (Holderness, 2009) shows that most of the companies in his sample have shareholders who own at least $5 \%$ of the firm's common stock and, when this is the case, the largest block holder has $26 \%$ of the stock.

Thus, while minority-elected directors are an interesting device for countries in which companies are well known to have concentrated ownership structures, as happens in most of Europe and Asia, even in the U.S. it may be the case to adopt corporate governance devices specifically aiming to the protection of minority shareholders, such as minority-elected directors.

Our research opens up future studies on corporate governance mechanisms that enhance other board tasks. Future studies may focus on changes in board functions, engagements of the boards towards their activities and board performance due to the presence of minority-elected directors. 


\section{Acknowledgements}

We thank Dimitri Guarino for his helpful comments. This article is the result of the author's common work. However, sections 3.2, 3.3., 4 and 5 should be attributed to Sara De Masi, sections 1, 2, and 3.1 to Andrea Zorzi and section 6 to both authors. This research has benefited from the research grant "Minority shareholder protection and slate (or list) voting in Italy. A theoretical and empirical analysis" awarded by University of Florence.

\section{References}

Armour, J., Enriques, L., Hansmann, H., \& Kraakman, R. (2017). The Basic Governance Structure: The Interests of Shareholders as a Class. In Kraakman, H. et al. (Eds.), The Anatomy of Corporate Law. A Comparative and Functional Approach (3rd ed., pp. 50-77). Oxford, England: Oxford University Press.

Balp, G. (2019). Activist Shareholders at De Facto Controlled Companies. Brooklyn J of Corporate, Financial \& Commercial L, 13(2), 341-393.

Barontini, R., \& Bozzi, S. (2011). Board Compensation and Ownership Structure: Empirical Evidence for Italian Listed Companies. Journal of Management and Governance, 15, 59-89.

Bebchuck, L. A., \& Fried, J. (2004). Pay without Performance: The Unfulfilled Promise of Executive Compensation. Cambridge, Mass.: Harvard University Press.

Bebchuk, L. A., \& Hamdani, A. (2017). Independent Directors and Controlling Shareholders. University of Pennsylvania Law Review, 165, 1271-1315.

Belcredi, M., \& Enriques, L. (2014). Institutional Investor Activism in a Context of Concentrated Ownership and High Private Benefits of Control: The Case of Italy. European Corporate Governance Institute (ECGI) Law Working Paper, 225/2013. http://dx.doi.org/10.2139/ssrn.2325421

Belcredi, M., Bozzi, S., \& Di Noia, C. (2013). Board elections and shareholder activism: the Italian experiment. In M. Belcredi, \& G. Ferrarini (Eds.), Boards and Shareholders in Italian Listed Companies (pp. 365-421). Cambridge, England: Cambridge University Press.

Bianchi, M., \& Enriques, L. (2001). Corporate Governance in Italy after the 1998 reform: what role for institutional investors? CONSOB Quaderni di Finanza, 43.

Bianchi, M., Ciavarella, A., Enriques, L., Novembre, V., \& Signoretti, R. (2014). Regulation and Self-Regulation of Related Party Transactions in Italy. European Corporate Governance Institute (ECGI) - Finance Working Paper, 415/2014; or CONSOB Working Papers No. 75. http://dx.doi.org/10.2139/ssrn.2383237

Claessens, S., Djankov, S., \& Lang, H. P. (2000). The Separation of Ownership and Control in East Asian Corporations. Journal of Financial Economics, 58, 81-112.

Claessens, S., Djankov, S., Fan, J., \& Lang, L. (2002). Disentangling the Incentive and Entrenchment Effects of Large Shareholdings. The Journal of Finance, 57(6), 2741-2771.

Comitato per la Corporate Governance. (2018). Codice di autodisciplina. Retrieved from https://www.borsaitaliana.it/comitato-corporate-governance/homepage/homepage.html

Consob. (2018). Report on corporate governance of Italian listed companies, Rome. Retrieved from http://www.consob.it/web/consob-and-its-activities/report-on-corporate-governance

Consob. (2019). Report on corporate governance of Italian listed companies, Rome. Retrieved from http://www.consob.it/web/consob-and-its-activities/report-on-corporate-governance

Core, J. E., Holthausen, R. W., \& Larcker, D. F. (1999). Corporate governance, chief executive officer compensation, and firm performance. Journal of Financial Economics, 51, 371-406.

Cornett, M. M., Guo, L., Khaksari, S., \& Tehranian, H. (2010). The impact of state ownership on performance differences in privately-owned versus state-owned banks: An international comparison. Journal Financial Intermediation, 19, 74-94.

Daily, C. M., \& Dalton, D. R. (1997), Separate, But Not Independent: Board Leadership Structure in Large Corporations. Corporate Governance: An International Review, 5, 126-136.

Dalton, D., Daily, C., Ellstrand, A., \& Johnson, J. (1998). Meta-analytic reviews of board composition, leadership structure, and financial performance. Strategic Management Journal, 19, 269-290.

Denis, D. K., \& McConnell, J. J. (2003). International Corporate Governance. The Journal of Financial and 
Quantitative Analysis, 38(1), 1-36.

Dick, A., \& Zingales, L. (2004). Private Benefits of Control: An International Comparison. The Journal of Finance, 59(2), 479-962.

Eisenberg, T., Sundgren, S., \& Wells, M. T. (1998). Large board size and decreasing firm value in small firms. Journal of Financial Economics, 48, 35-54.

Enriques, L. (2018). Related Party Transactions. In Gordon, J. N. \& Ringe, W. (Eds.), Oxford Handbook on Corporate Law and Governance (pp. 506-531). Oxford, England: Oxford University Press.

Enriques, L., \& Volpin, P. (2007). Corporate Governance Reforms in Continental Europe. Journal of Economic Perspectives, 21(1), 117-140.

Enriques, L., Hansmann, H., Kraakman, R., \& Parglender, M. (2017). The Basic Governance Structure: Minority Shareholders and Non-Shareholder Constituencies. In Kraakman, H. et al. (Eds.), The Anatomy of Corporate Law. A Comparative and Functional Approach (3rd ed., pp. 79-108). Oxford, England: Oxford University Press.

Erede, M. (2013). Governing Corporations with Concentrated Ownership Structure: An Empirical Analysis of Hedge Fund Activism in Italy and Germany, and Its Evolution. European Company and Financial Law Review, 328-393.

Faccio, M., \& Lang, L. H. P. (2002). The Ultimate Ownership of Western European Countries. Journal of Financial Economics, 65, 365-395.

Ferrarini, G., \& Filippelli, M. (2014). Independent Directors and Controlling Shareholders Around the World, European Corporate Governance Institute (ECGI) - Law Working Paper, 258/2014. Retrieved from https://ssrn.com/abstract=2443786 or http://dx.doi.org/10.2139/ssrn.2443786

Financial Times. (2017). Activist investors lead 'quiet revolution' in Italy. Retrieved from https://www.ft.com/content/d6a695ee-6df2-11e7-bfeb-33fe0c5b7eaa

Gelter, M. (2012). Why Do Shareholder Derivative Suits Remain Rare in Continental Europe? Brooklyn Journal of International Law, 37(3), 843-892.

Gilson, R. J., \& Gordon, J. N. (2019). The Rise of Agency Capitalism and the Role of Shareholder Activists in Making it Work. Journal of Applied Corporate Finance, 31(1), 8-22.

Glantz, S. A., Slinker, B. K., \& Neilands, T. B. (2016). Primer of Applied Regression \& Analysis of Variance. New York, NY: McGraw Hill Education.

Goergen, M. (2012). International Corporate Governance. Harlow, Essex: Pearson Education

Gordon, J. (1994). Institutions as Relational Investors: A New Look at Cumulative Voting. Columbia Law Review, 94(1), 124-192.

Goshen, Z., \& Squire, R. (2017). Principal Costs: A New Theory for Corporate Law and Governance. Columbia Law Review, 117, 767-803.

Hill, J. G. (2018). Good activist/bad activist: The rise of international stewardship codes. Seattle University Law Review, 41(2), 497-524.

Hirschman, A. (1971). Exit, Voice and Loyalty: Responses to Decline in Firms, Organizations, and States. Cambridge, Massachusetts: Harvard University Press.

Holderness, C. (2009). Myth of Diffuse Ownership in the United States. Review of Financial Studies, 22(4), $1377-1408$.

Kahan, M., \& Rock, E. (2011). When the Government is the Controlling Shareholder, Faculty Scholarship. Paper 316. Retrieved from http://scholarship.law.upenn.edu/faculty_scholarship/316

Kreyszig, E. (1979). Advanced Engineering Mathematics. London: Wiley.

Marchetti, P., Siciliano, G., \& Ventoruzzo, M. (2017). Dissenting Directors. European Business Organization Law Review, 18, 659-700.

Marchetti, P., Siciliano, G., \& Ventoruzzo, M. (2020). Disclosing Directors. European Business Organization Law Review, 21, 219-251.

Minichilli, A., Zattoni, A., \& Zona, F. (2009). Making Boards Effective: An Empirical Examination of Board Task Performance. British Journal of Management, 20, 55-74. 
Morck, R., \& Yeung, B. (2003). Agency problems in large family business groups. Entrepreneurship Theory and Practice, 27, 367-382.

Morck, R., Yeung, B., \& Zhao, M. (2008). Perspectives on China's outward foreign direct investment. Journal of International Business Studies, 39, 337-350.

Nielsen, S., \& Huse, M. (2010b). The contribution of women on boards of directors: Going beyond the surface. Corporate Governance: An International Review, 18(2), 136-148.

Opler, T. C., \& Sokobin, J. (1996). Does Coordinated Institutional Shareholder Activism Work? An Analysis of the Activities of the Council of Institutional Investors. Dice Center for Research in Financial Economics, Working Papers Series 95-5. http://dx.doi.org/10.2139/ssrn.46880

Passador, M. L. (2018). List Voting's Travels: The Importance of Being Independent in the Boardroom. Fordham Journal of Corporate and Financial Law, 24, 1-50.

Poczter, S. (2016). Can monitoring improve the performance of state-owned firms? Evidence from privatization in a large emerging market. Industrial and Corporate Change, 25(6), 903-921.

Rock, E. B. (2018). Institutional Investors in Corporate Governance. In Gordon, J. N. \& Ringe, W. (Eds.), Oxford Handbook on Corporate Law and Governance (pp. 363-386). Oxford, England: Oxford University Press.

Shleifer, A., \& Vishny, R. W. (1997). A Survey of Corporate Governance. Journal of Finance, 52(2), 737-783.

Smith, M. P. (1996). Shareholder Activism by Institutional Investors: Evidence from CalPERS. Journal of Finance, 51(1), 227-252.

Strampelli, G. (2018). How to Enhance Directors' Independence at Controlled Companies. J. Corp. L., 44, 103-150.

Ventoruzzo, M. (2007). La composizione del consiglio di amministrazione delle società quotate dopo il d.lgs. $\mathrm{n}$. 303 del 2006: prime osservazioni, Rivista delle società, 205-251.

Wooldridge, J. W. (2008). Introduction to Econometrics: A modern Approach. Cengage Learning.

Yermack, D. (1996). Higher market valuation of companies with a small board of directors. Journal of Financial Economics, 40,185-211

Zona, F., \& Zattoni, A. (2007). Beyond the black box of demography: Board process and task effectiveness within Italian firms. Corporate Governance: An International Review, 15, 852-864.

\section{Copyrights}

Copyright for this article is retained by the author(s), with first publication rights granted to the journal.

This is an open-access article distributed under the terms and conditions of the Creative Commons Attribution license (http://creativecommons.org/licenses/by/4.0/). 